\title{
Analyses of morphobiochemical characteristics of the Iris genus within the conditions of the Kuzbass botanic garden
}

\author{
Oxana Vronskaya ${ }^{1 *}$, and Oxana Tsandekova ${ }^{2}$ \\ ${ }^{1}$ Federal Research Center of Coal and Coal Chemistry of Siberian Branch of the Russian Academy of \\ Sciences, 650065, Kemerovo, Leningradskiy pr., 10, Russia \\ ${ }^{2}$ Federal Research Center of Coal and Coal Chemistry of Siberian Branch of the Russian Academy of \\ Sciences, 650065, Kemerovo, Leningradskiy pr., 10, Russia
}

\begin{abstract}
The results of study of adaptation potential of plants of the Iris genus of Iridaceae within the conditions of the Kuzbass botanic garden are represented in the article. It was made the evaluation of Morphobiologic characteristics of irises, the terms of flowering was determined together with duration and productivity of flowering, different capacity to fructification was marked, and the sums of positive temperatures need to such phonological phases of development, as growth, flower-bud formation, flowering and fructification were determined. The overall estimate over the complex of decorative signs showed that they are original and stable in the local conditions and may be recommended for commercial floriculture and greening within the conditions of Kemerovo region.Studied an indicating role of phenol compounds, peroxidases, ascorbic acid in Iris leaves during seasonal development. Analyses of studies revealed that the level of biochemical values in the leaves of decorative perennials growing on the territory of the Kuzbass botanic garden depended from species peculiarities and vegetation period of plants. Within the period of vegetation the most accumulation of ascorbic acid was revealed. The studied figures may be used as an informative parameter for the plants state evaluation for further phytoindication and introduction.
\end{abstract}

Biodiversity is a common heritage, it plays vital role for the present and future generations. The growth of population due to economic activity of humans leads to irreversible alterations of our planet. Some definite kinds and ecosystems are threatened with extinction. The botanic gardens are engaged in active work for studying and keeping of a natural genofond. The species of Iris genus are studied widely in many regions of Russia and abroad [1-11]. The collection of Iris genus is represented in the Kuzbass botanic garden which takes about 10 species and more than 40 varieties. We make evaluation of morphobiological possibilities of introduced species which allows to define a seasonal rhythm of development and to evaluate winterhardines, drought hardness, decorativeness, peculiarities of reproduction in the definite terms of its cultivation. Evaluation of physiologic capabilities consists in study of figures of photosynthetic apparatus, i.e. the

\footnotetext{
${ }^{*}$ Corresponding author: oksana_vronski@mail.ru
} 
contents of a and b chlorophylls and carotenoid in the leaves. Analyses of morphobiological and biochemical figures allows to understand as the plants assimilated to the environment conditions of the given region. Such common evaluation is very rare so it very actual today.

The goal of study is the analyses of morphobiological and biochemical characteristics of Iris genus within the conditions of the Kuzbass botanic garden.

Objects and methods. Work was carried out in years 2016-2019 on the territory of the Kuzbass botanic garden (Kemerovo) located in the north part of forest-steppe zone of Western Siberia. The climate of the region under research is a sharply continental. An average annual temperature of air is $0,9{ }^{\circ} \mathrm{C}$. The highest air temperature is in summer $\left(35 \ldots 38{ }^{\circ} \mathrm{C}\right)$, and the lowest air temperature is in winter $\left(-57^{\circ} \mathrm{C}\right)$. The first spring frosts take place in the period from May $28^{\text {th }}$ till June $11^{\text {th }}$, and the first autumn frosts begin from August $26^{\text {th }}$ till September $14^{\text {th }}$. An average annual precipitation is about $450 \ldots 500 \mathrm{~mm}$. The snow cover height varies from 47 to $72 \mathrm{~cm}$. Two kinds of the Kuzbass flora were taken as the object:

Iris bloudowii Ledeb. - is a redivive short rhizogenous policarpous plant. Grow on subalpine meadows on meadow sidehills of mountains, forest edges and shore meadows [12]. In Kemerovo region you may find it in Tashtagol district, $20 \mathrm{~km}$ upstream the Kabyrza river near the village Ust-Kabyrza. It is recorded in the Red Book of Kemerovo region with a status 1 as endangered plant [13].

Iris ruthenica Ker Gawl. - is a redivive tracing root rhizogenous policarpous plant. Grow in coniferous, mixed light forests [12]. Grow throughout all the districts of Kemerovo region.

Phenological observations were spent in compliance with the methodic of phenological observations in botanic gardens [14]. Evaluation of perspectivity of a primary introduction of species and varieties of liliums was given according to the methodic of A.N.Kuprianova [15]. Decorativeness was evaluated according to the Methodic of native strain testing of agricultural plants [16]. Biochemical studies were carried out by the contents of ascorbic acid and phenol compounds. The contents of ascorbic acid was determined by the titrationbased method with 2,6-dichlorophenol-indophenol [17], phenol compounds - according to Leventhal- Neubauer method, based on the light oxidation of phenols with potassium permanganate in presence of indigo-sulphacid at room temperature up to golden yellow coloring [18]. Triple replication of experiments on the base of the mixed sample. Data are represented in kind of average arithmetical values and their standard mean square errors. Statistical processing of findings was made using the standard package StatSoft STATISTICA 8.0.

Beginning of regrowth of irises came from the second decade of April till the second decade of May with the sum of positive temperatures of $190-217^{\circ} \mathrm{C}$. The first irises flower buds appeared in 15-25 days after regrowth with the sum of positive temperatures of 310$380^{\circ} \mathrm{C}$. Initial blossom of the species under research began in 17-27 days from the date of budding beginning. Blossom - time of the first flowers of I. bloudowii and I. ruthenica began in the third decade of May - beginning of the first decade of June with the sum of positive temperatures of $313-389{ }^{\circ} \mathrm{C}$. At the average the duration of irises blossom time amounted to 14-21 days.

Diameter of flower of Iris ruthenica is 3-6 cm, and of Iris bloudowii 4-6 cm. Flowers break down early in the morning, but in hot and dry weather flower buds opening may occur in the day-time. Pollen sacs open simultaneously with the flower opening or just after its opening. Pollen drop quickly out the pollen sac, and often by the evening of the first day the pollen sac become empty. Pollen is homogenous, viable pollen grains of Iris bloudowii counts average $-33 \%$, and Iris ruthenica $-87.1 \%$. 
The irises blossom productiveness depends on duration of one flower blossoming. In the conditions of the Kuzbass botanic garden duration of one flower of Iris ruthenica, Iris bloudowi lasts from 3 to 7 days.

It was defined a different ability to fructification of irises: Iris ruthenica - fruits set and ripen all over the years of study, as the Iris bloudowii showed the fail of fruit formation all over the years of study.

Overall estimate of a complex of decorative signs amounted to 95 points for the both species. They are original and persistent in local conditions and may be recommended for commercial floriculture and greening within the conditions of Kemerovo region.

An important role in the period of the plant's growth and development belongs to some biochemical figures which take part in various processes of photosynthesis and breath of plants. They allow to analyses in detail the plant's state and to detect the most changeable parameters of their metabolism. Detection of the compliance of growth conditions of decorative perennial to its biological requirements to different natural and climatic conditions is highly relevant.

Analyses of made studies showed that the level of biochemical figures in the leaves of decorative perennial growing on the territory of the Kuzbass botanic garden depended on specie characteristics and vegetative period of plants (see table 1).

Table 1. Static characteristics of biochemical figures of irises

\begin{tabular}{|l|l|l|l|l|l|l|}
\hline Figures & Average & $\begin{array}{l}\text { Standard } \\
\text { errors }\end{array}$ & Minimum & Maximum & $\begin{array}{l}\text { Standard } \\
\text { deviation }\end{array}$ & $\begin{array}{l}\text { Coefficient } \\
\text { of } \\
\text { variation, } \\
\%\end{array}$ \\
\hline \multicolumn{7}{|c|}{ Iris bloudowii Ledeb. } \\
\hline $\begin{array}{l}\text { Ascorbic acid, } \\
\text { mg/100g }\end{array}$ & 42.60100 & 5.176071 & 20.20200 & 69.42000 & 17.93043 & 42.0892 \\
\hline $\begin{array}{l}\text { Peroxidase, } \\
\text { activity unit }\end{array}$ & 2.23136 & 0.666317 & 0.66667 & 6.25000 & 2.30819 & 83.4432 \\
\hline $\begin{array}{l}\text { Malonyldialdehyde } \\
\text { (MDA), nmol/g }\end{array}$ & 6.74731 & 0.697663 & 2.81720 & 9.24731 & 2.41678 & 35.8184 \\
\hline $\begin{array}{l}\text { Phenol } \\
\text { compound,\% }\end{array}$ & 0.87566 & 0.040945 & 0.69283 & 1.15472 & 0.14184 & 16.1977 \\
\hline & 19.27250 & 2.532252 & 10.92000 & 32.37000 & 8.771979 & 45.51552 \\
\hline $\begin{array}{l}\text { Ascorbic acid, } \\
\text { mg/100g }\end{array}$ & 10.43747 & 0.643932 & 7.69231 & 14.28571 & 2.230645 & 41.37151 \\
\hline $\begin{array}{l}\text { Peroxidase, } \\
\text { activity unit }\end{array}$ & 7.62903 & 0.745406 & 4.94624 & 10.38710 & 2.582163 & 33.84653 \\
\hline $\begin{array}{l}\text { Malonyldialdehyde } \\
\text { (MDA), nmol/g }\end{array}$ & 0.78329 & 0.037869 & 0.60046 & 0.99306 & 0.131182 & 16.74763 \\
\hline $\begin{array}{l}\text { Phenol } \\
\text { compound,\% }\end{array}$ & &
\end{tabular}

During vegetation the most accumulation of ascorbic acid was detected in leaves as compare with the other figures. It was detected that the level of ascorbic acid contents in leaves of irises in vegetation period varied within the limits of figures from $10.92 \mathrm{mg} / 100 \mathrm{~g}$ to $69.42 \mathrm{mg} / 100 \mathrm{~g}$, where the biggest accumulation of ascorbic acid was defined in leaves of I. bloudowii, i.e. in 1.8-2.1 times higher than of $I$. ruthenica. From the beginning of vegetation the level of ascorbic acid in the irises leaves increases and reaches its maximum figure in the phase of budding, then, this figure decreases as the leaves age. Probably in the period of the plants active growth, the vegetative organs are developed the most active having accumulating much ascorbic acid for its further transformation to reproductive organs of plants. 
Values of peroxidase activity and intensity of lipid peroxygenation in leaves of irises took an intermediate position between biochemical figures. Thus, peroxidase activity varied between the figures from 0.66 to 14.3 units of activity. To the end of vegetative period the enzyme activity of the studied samples increased, which probably caused by the plants natural ageing. In the bud-formation period of irises the minimal values of the studied figure were detected ( $0.67-0.74$ units of activity), at that, in the leaves of I. bloudowii they were lower in 1,1 times as compare with I. ruthenica. The level of malonyldialdehyde was within the limits of values from 2.8 to $10.4 \mathrm{nmol} / \mathrm{g}$. It was observed some decrease of this value between the beginning of vegetation and the bud-formation period to $3,20 / \mathrm{nmol} / \mathrm{g}$ and its increase to the end of vegetation up to $10.24 \mathrm{nmol} / \mathrm{g}$. In the leaves of $I$. bloudowii we noted the lowest level of MDA (at average lower by $12 \%$ ) than in the leaves of $I$. ruthenica.

In the leaves of decorative perennial the most contents of phenol compound was defined in the phase of fructification (0.96-1.05\%) and the lowest - in the period of bud formation $(0.62-0.70 \%)$. In the leaves of I. bloudowii it was revealed the highest level of accumulation of the studied figures (from $0.70 \%$ to $1.05 \%$ ) in the period of vegetation that is in 1,1 times higher than in the leaves of I. ruthenica.

Analyses of values of coefficients of variation of biochemical figures of decorative perennial revealed large homogeneity of a level of phenol compound and malonyldialdehyde, i.e. less changeability of a characteristic as compare with the Peroxidase activity and the contents of ascorbic acid.

Evaluation of variability of studied figures detected differences of coefficients of variation calculated for different species of irises. A break in the peroxidase activity changeability of $I$. rythenica reduced in 2 times and in the level of malonyldialdehyde - in 1.1 times in comparison with I. bloudowii.

On the ground of experimental data we made calculation of correlation relationships between morphological and biochemical figures of studied plants (table 2). The closest negative relationship was found between the peroxidase activity and a width of a leaf, and positive correlation - between peroxidase activity and bush diameter, and also between ascorbic acid and a leaf width.

Table 2. Correlation relationships of morphologic and biochemical figures of irises

\begin{tabular}{|c|c|c|c|}
\hline Figures name & a leaf & $\begin{array}{ll}\text { a leaf } & \text { Width of } \\
\end{array}$ & $\begin{array}{l}\text { Diameter of a } \\
\text { bush }\end{array}$ \\
\hline Ascorbic acid & -0.23 & 0.65 & 0.61 \\
\hline Peroxidase activity & 0.41 & -0.81 & $0, .86$ \\
\hline MDA & 0.14 & $-0,21$ & 0.15 \\
\hline Phenol compound & -0.13 & 0.29 & -0.37 \\
\hline
\end{tabular}

Note: The mentioned correlations at significance value $\mathrm{p}<0.05$

The work was made within the limits of National task of The Federal Research Center of Coal and Coal Chemistry of Siberian Branch of the Russian Academy of Sciences AAAA-A17117041410053-1 (Project № 0352-2016-0002) «Evaluation of a state and protection of floristic variety affected by anthropogenic and technogenic factors in situ и еx situ». On the base of USS Introduction fund KuzBS № USU 508670

\section{References}

1. O. V. Dorogina, V. M. Doronkin, I. Yu. Selyutina, E. S. Konichenko, Turczaninowia, 15, 76-81 (2012) 
2. M. Sh. Minzhal, V. A. Boldyrev Izv. Sarat. UN-TA. Ser. Chemistry. Biology. Ecology, 16, $404-41,(2016)$

3. A. Yu. Nabieva, T. V. Elisafenko, Turczaninowia, 1, 80-84 (2012)

4. A. Wróblewska, E. Brzosko, Ç Czamecha, J. Nowosielski, Bot. J. Linn. Soc. 142, 6572 (2003)

5. A. Guvenc, Turkish J. Pharm. Sci, 2, 125-136 (2005)

6. F.O. Khassanov, Stapfia, 97, 174-179 (2012)

7. M. Colasante, V. Mathew, Plant Biosys., 142, 172-178 (2008)

8. N Tillie, M. W. Chase, T. Hall, Annali di botan., 58, 105-112 (2000)

9. V. P. Karpenko, Visnik of the Uman National University of Gardening, 2, 85-89 (2015)

10. Bozena Mitic, Plant Syst Evol, 299,271-288 (2013)

11. E. Oybak Donmez, S Isik, Grana, 47, 15-38, (2008)

12. N. V. Vlasova, V. M. Doronkin, N. I. Zolotukhin, Flora of Siberia. Araceae-Orhidaceae (Novosibirsk, Publishing house of the SB RAS, 1987)

13. Red book of the Kemerovo region: Vol. 1. Rare and endangered species of plants and fungi, 2nd ed. (Kemerovo, Irbis, 2012)

14. Methods of phenological observations in the Botanical gardens of the USSR (Science, Moscow, 1975)

15. A. N. Kupriyanov, Theory and practice of plant introduction: textbook (KREOO "Irbis", Kemerovo, 2013)

16. Methods of state variety testing of agricultural crops: Decorative crops, 223, (1968)

17. O. A. Neverova, Workshop on biochemistry, (Kemerovo, KemTIPP, 2005)

18. I. M. Korenskaya, N. P. Ivanovskaya, I. E. Izmalkova, Medicinal plants and medicinal plant raw materials containing anthracene derivatives, simple phenols, lignans, tannins, (Voronezh State University Publishing House, Voronezh, 2007) 